\title{
Surfaces
}

\section{INSIDERS AND OUTSIDERS}

\section{Hazard Adams}

Volume 4, 1994

CONFÉRENCE INTERNATIONALE SUR LE DISCOURS HUMANISTE (PREMIÈRE RENCONTRE, 3-8 AVRIL, 1994)

INTERNATIONAL CONFERENCE ON HUMANISTIC DISCOURSE (FIRST MEETING, APRIL 3-8, 1994)

URI : https://id.erudit.org/iderudit/1064972ar

DOI : https://doi.org/10.7202/1064972ar

Aller au sommaire du numéro

Éditeur(s)

Les Presses de l’Université de Montréal

ISSN

1188-2492 (imprimé)

1200-5320 (numérique)

Découvrir la revue

Citer cet article

Adams, H. (1994). INSIDERS AND OUTSIDERS. Surfaces, 4. https://doi.org/10.7202/1064972ar
Résumé de l'article

L'auteur prend pour thème le principe humaniste du discours antithétique, tel que véhiculé dans la tradition littéraire irlandaise. Mettant en évidence les différences entre les perceptions américaines (externes) et irlandaise (internes) des écrivains irlandais, il décrit les fluctuations dans les jugements critiques concernant les positions relatives de Yeats et de Joyce dans la tradition. 


\title{
INSIDERS AND OUTSIDERS
}

\author{
Hazard Adams
}

\begin{abstract}
This essay takes as its theme the humanistic principle of antithetical discourse as exemplified in the Irish literary tradition. In demonstrating the differences between external American views and internal Irish views of Irish writers, it traces the changing critical judgments of Yeats' and Joyce's respective places in the tradition.
\end{abstract}

\section{RÉSUMÉ}

L'auteur prend pour thème le principe humaniste du discours antithétique, tel que véhiculé dans la tradition littéraire irlandaise. Mettant en évidence les différences entre les perceptions américaines (externes) et irlandaise (internes) des écrivains irlandais, il décrit les fluctuations dans les jugements critiques concernant les positions relatives de Yeats et de Joyce dans la tradition. 
The series of questions posed by Wolfgang Iser and Murray Krieger is daunting indeed. I don't know whether the discourse I am about to present is humanistic, marginal, elitist, arrogant, interested, disinterested, most of these, or merely off the point. I fear that if I attempt to engage such questions head on I shall never write. I am going to be concerned here, on what I'll call a practical level, with the problem of conversation (specifically literary criticism) across divisions. In my ignorance I am intrigued by the problem of conversation across the Pacific, as it involves negotiating the differences of written languages, and particularly the traditions of literary criticism East and West. I know very little about criticism in eastern Asia and nothing of east Asian languages, but I believe that the next few decades will be concerned with the negotiation of these differences and that in, say, twenty years an anthology like Critical Theory Since Plato will look quite different -- to say nothing of one like Critical Theory Since 1965. Eastern and Western critical traditions are meeting, and the next great movement in the discourse of criticism and theory is even now being generated by that convergence.

In searching for something I might conceivably offer as a model for determining what the problems are going to be (or already are), it occurred to me that something with which I have a degree of familiarity might be of modest use. This is the contrast over our century of American and Irish criticism of Irish literature, especially that of Yeats and Joyce. It can be no secret to anyone who has studied the reception of these writers in Ireland and America that it has been significantly different. (I deliberately leave out England and France because of the limitations of space.)

My idea of taking Ireland as a model is not entirely idiosyncratic. Ireland is perhaps a synecdoche. As early as the eighteen-forties, Gustave de Beaumont wrote, "Ireland is a little country that gives rise to debate on the greatest questions of politics, morality, and humanity," and Harvey Cox, who quotes Beaumont in a recent article in the London Observer describing the new Irish studies program at Liverpool, strikes a note common in recent discourses about Ireland:

There is much more to Ireland than Guinness and conflict. The study is also of wider intellectual value. Ireland today presents issues of more general concern, including regional, economic development and decline, the role of religion in society, migration, and its effects, nationalism and postnationalism, law and the State under stress of violence, communal conflict and conflict regulation. [1]

Reviewing Brian P. Kennedy's Dreams and Responsibilities, The State and the Arts in Independent Ireland, Maryann G. Valuelis remarks, "The Irish experience is most likely typical of many post-colonial countries and it would 
be interesting to compare the Irish record with countries of similar economic and political status."[2] Reviewing David Lloyd's Anomalous States: Irish Writing and the Post-Colonial Moment, Joyce Flynn writes, "The thoughtful reader may [ask about] the hegemonic role that first-world critics and theorists play or see themselves playing in relation to creative artists in all geographies, particularly those creating for audiences that include the impoverished, the illiterate and the dislocated."[3]

I am tempted to ask why American and Irish treatment of the greatest Irish writers has been so different, though far less different now than in the past. Is it possible to generalize from this situation toward a set of questions to ask about any situation of insiders and outsiders? Are there specific, obvious dividing forces embedded in Irish history and culture: colonialism, religion, and territorialism? (One is tempted, of course, to add language, though with special qualifications. But then, the others need qualification, too.) Has American culture produced an angle of critical vision distinctly different from that which has been imbedded in these forces?

I sense hope of producing a model slipping away into the particularities of history, but perhaps to see this occurring is itself a help.

When I began writing on Yeats early in the fifties, there had been very little serious criticism of either Yeats or Joyce in Ireland. Not so in America. Already a Joyce industry -- though still a cottage industry -- was being formed, and the New Critics had accepted Yeats, though with some puzzlement and occasional irritation at his romanticism and occultism. American critics tended to see Joyce as an international writer and an endorsement of their own modernism. Above all, I think, the modes of American criticism that were attracted to Yeats and Joyce tended to be of the sort oriented to writerly, or what R. P. Blackmur called "technical," concerns. Either that, or the more broadly cross-cultural interests of mythic and archetypal criticism, a movement arguably a product of romanticism and friendly to both Yeats and Joyce. Why was there so little critical activity in Ireland, and why was much of it just this side of scornful toward its major figures, as if it had been uttered by the Citizen of Joyce's Ulysses? Indeed, that is not at all a bad analogy, for Joyce's Citizen inveighed against the outsider Leopold Bloom. But Bloom was also a bit of an insider. He could claim to have been born in Dublin. Irish criticism complained about American critics as if they were intellectual versions of the Norman invaders.

In those days Ireland was languishing somewhere between a colonial and postcolonial condition. The Irish Times, the major outlet for literary reviewing, was still to a great extent a colonial outpost, as was Trinity College. Even as late as the early sixties, when I taught there, my students were almost all English or French. A Catholic had to secure permission of 
the Bishop of Dublin to attend. Even among Anglo-Irish critics treatment of Irish writers was mainly anecdotal and frequently a trafficking in mockery (to steal a line from Yeats). The attitude toward American scholars was little better than that moving between wry amusement and wry resentment. It often took the form of anecdotes about Americans' piratical affluence and penchant for gathering trivia or making ignorant gaffes about matters of common knowledge to Dubliners. It was particularly expressed in observations about the hordes of Joyce scholars who descended on Dublin from America and carried off indiscriminately whatever they could collect for their wealthy libraries. The first Irish scholar I met in Dublin expressed relief that at least I had not come to work on Joyce!

But the Irish frequently expressed resentment against or contempt for the great Irish writers themselves. To this day an Irish novelist friend somewhat older than myself refers to Yeats always as "poor silly Willy." Early in the fifties, an Irish priest, upon learning that I was writing on Blake and Yeats, expressed the hope that I would say they were both "a bit cracked." Perhaps that was fair enough; I had heard worse from my own American teachers, but they would refer only to Blake in that way. It is more significant that the director of the National Library of Ireland, himself a well known historian, was surprised that I wanted to see Yeats's letters to John O'Leary. Why, only a few days ago an American had been in to see them. Surely there wasn't anything more of interest there. It turned out after questions that the earlier fellow had been Richard Ellmann five years before. American critics were routinely trounced in the Irish Times. When I remonstrated in behalf of one of them by letter (my first publication) the offending columnist turned serious (in the $O^{\prime}$ Casey sense) and declared, "We Irish have such great respect for learning that we rarely dare to approach it."[4] One wondered who had been taken in this cross-cultural skirmish.

Of Yeats's generation and those before it back into the eighteenth century virtually all the major Irish writers were Protesant, which is to say AngloIrish descendants of either the Ascendancy or the merchant and professional classes. The major exception was, of course, Joyce, but he was an apostate. Furthermore, many lived mostly abroad, and some like Joyce, Shaw, O'Casey, and Beckett permanently. It is not too much to say that the colonialist condition and its sectarian history drove a wedge between the Irish populace and its writers. Catholic peasants and city dwellers were poor, ill educated, of a religion that over history had separated them from an invader who had caused them to be dispossessed of land and native language. This history strongly affected the behavior of Irish critics toward their own writers, and the resentment flowed over to critics on the outside.

Furthermore, the colonial situation, beset by an internal religious difference, exacerbated by economics and expatriation, made Joyce and Yeats look different inside Ireland from the prevailing view outside. The Irish had some trouble determining what all the fuss over them was about, and particularly, I think, they resented the external fuss over Joyce, who was a special embarrassment. That resentment didn't wane until the Church's control slackened. Yeats's nationalism, as I have tried to show elsewhere, had an 
antithetical quality -- a sort of nationalism against nationalism as it was practiced -- that few appreciated, and he was from Protestant stock.[5] Joyce had written a book that he was unable to publish in Ireland and then one officially banned for decades. The judgments on Yeats and Joyce were politico-religious in a situation where religion and politics were closely related.

All of this was either relatively unimportant to critics on the outside or not well understood by those who could confuse William of Orange with Kaiser Wilhelm (with respect to Yeats's poem "Lapis Lazuli").

Then came changes. I shall put aside one of them with only brief mention for lack of space, though it is of considerable interest: Yeats and Joyce began to be of economic interest to the Irish tourist industry. This change helped bring the inside and outside a little closer together. Irish universities grew, a younger generation was not so tied to the Church, or not in the same way. Communication between critics inside and outside became easier. Publishing developed. The emergence of significant Catholic writers eased old attitudes. /pp. 9-10/

But if American critics had initially championed Yeats, Joyce, and others, it was the Irish critics who would treat Yeats and Joyce in a new way. This way has been influential with the development of Irish studies in American universities and the politicization of much literary criticism. The newer Irish critics pitted Joyce against Yeats, and the reasons were political and local. Irish critics were engaging themselves in a national cultural criticism of a sort and at a level that had not been seen in America. Their predecessor in this matter was Yeats, but now Yeats was the monolithic force to be opposed, and Joyce was a possible weapon. (There is not space here to consider what Yeats and Joyce thought about each other, though it is instructive.) Yeats was seen to be the perpetuator or even the creator of a romantic myth of the Celtic Twilight that was outmoded and complicit with colonialist views that had to be overthrown. This was more or less the earlier Yeats; the later was even more egregiously at fault for having invented the nostalgic myth of Anglo-Irish Ireland.

Against this two-headed monster there was made to stand Joyce, who was Catholic enough, looked Irish life straight in the eye, debunked the Celtic Twilight and nationalism itself, in part by the very fact of his exile. For Seamus Deane, perhaps the leading critic practicing this revisionism, Yeats's two "seductive" fictions were simply false. They were prolongations of the old romantic polemic against the Enlightenment, "a romantic aesthetic heritage with which we still struggle." For Deane, "It clearly harbours the desire to obliterate or reduce the problem of class, bureaucratic organization, and the like, concentrating instead upon the issues of self, community, nationhood, racial theory, zeitgeist."[6] In other words, Yeats's 
myth cannot cope with the situation of North and South in Ireland, which is the one compelling issue, to be answered by turning to concerns that transcend nationalism and seeing things principally in transnational economic terms and the class struggle.

The principal or at least most notorious response to Deane and others was made by the American scholar of the work of Sean O'Casey, David Krause, in an angry article entitled "The De-Yeatsification Cabal":

It is a misbegotten and intolerant revisionism, based upon political bias rather than aesthetic judgment, and therefore highly suspect. It is now an appropriate time to confront and expose the vindictive Irish hounds who are again trying to bring down a noble stag.[7]

Krause's defense invoked a task for the critic that was familiar to American modernist criticism, but not central to Deane's interests. It drew the fire of a generation of critics who had been moved to political agendas. Thus Deane had a friendly audience for the most part, but no one seemed to want to be identified in print with Krause: "Should the critic examine what the poem or painting does rather than what it supposedly and reductively says or means, in relation to its relevance or utility to a particular cause or ideology [...]?"(5) Without necessarily siding with the political critics, one can see problems accumulating as this brief passage proceeds. Is Krause's "aesthetic judgment" a narrow formalism? What is meant by "what the poem or painting does"? Is there included in "doing" the possibility of sending men out to be shot, as Yeats imagined his play Cathleen ni Houlihan possibly to have done? And so on. Yeats thought poems had political consequences. The argument against Deane (and possibly against Krause) requires more space than Krause himself had and a ground not vulnerable to the old socialist attacks on formalism.

As far as I know, there is no serious case being made against Joyce on either side of the Atlantic. In Ireland the case for him made by the Yeats detractors seems to begin from a championing of a sort of social realism, telling it as it is. One knows that this

will hardly do and is in its own way as retrograde as naive aestheticism.

Can I reach any conclusions here about inside and outside that might extend beyond Ireland inside and America outside (but with its own inside)? Mostly in the form of questions and occasionally a tentative answer. 
Can the outsider see more clearly? Was Heraclitus right about the value of remote vision? Or does the outsider merely see something else with a certain myopia? Will the insider's view be inevitably more political, activist -engaged? I suspect so. Will this make it critically more astute? Not necessarily. In all likelihood, it will be quite opinionated, and in a postcolonial situation it is likely to be inspired by a political view that tends to reductive judgment.

Is a postcolonial insider likely to opt for the naive realism that in part turned young Irish writers from Yeats to Joyce and thence to Patrick Kavanagh? In his study of post-Yeatsian Irish poetry, Robert F. Garratt writes:

The younger poets [...] have declared that Yeats's view of Ireland is selfserving romanticism bred out of bitter self-imposed isolation; they have then opted in their own poetry for the treatment of Irish reality, a scrutiny of the common experience of life as lived by most of the people. Once the Yeatsian tradition could be shown to be both limited and specious, particularly in its insistence upon continuity, then the younger poets could offer their own treatment of Irish experience as innovative and, more important, as authentic.[8]

Whether the Yeatsian tradition is more limited than what endeavored to replace it is a question that needs to be further addressed. Was the shift entirely politically driven? Not entirely. The Yeatsean voice was so powerful that for some time young poets had trouble freeing their own voices. But the attachment to Joyce seems strongly in line with the politics (though one wonders what Joyce would have thought of it, for he was much less overtly political than Yeats). Can the outsider ever approach the urgency with which insiders debate their political questions? I doubt it. Nor should they.

What can the outsider see that the insider disregards or suppresses? I think that the outsider is more likely to view a writer in terms of the traditions of poetic making. By virtue of a certain distance the outsider is likely to treat Yeats as an innovative voice in a line of poetry as techne, as one who says things sayable best or perhaps only as poetry. No doubt Deane appreciates this strength in Yeats, but for him it is beside the point, except in its seductive power to delude us or move us from what is important.

Among contemporary Irish poets Seamus Heaney has continued to admire Yeats, while acknowledging the personal importance of Kavanagh. He attempts both an insider's and outsider's view: 
I admire the way that Yeats took on the world on his own terms, defined the areas where he would negotiate and where he would not, the way he never accepted the terms of another's argument but propounded his own. I assume that this peremptoriness, this apparent arrogance, is exemplary in an artist, that it is proper and even necessary for him to insist on his own language, his own vision, his own lines of reference.[9]

Or am I deluding myself about Heaney, and myself. I am on a particular outside by virtue of my own circumstances. I was a student when most politically oriented criticism seemed crude and reductive. I studied in a period of the New Criticism followed by mythic and archetypal criticism and the resurgence of interest in romanticism.

Would most Chinese critics reading Yeats treat him as many Americans have done? Or would for them the political be the guiding principle? Or is there another vision we in America and Ireland have all missed? A knowledge of the traditions of Chinese criticism would be required to answer these questions.

The better test may in this case be Japan, which for decades has had a vigorous Yeats society, perhaps because of Yeats's own interest in the Noh drama. The best Japanese book on Yeats, to my knowledge, is Okifumi Komesu's The Double Perspective of Yeats's Aesthetic, not at all politically inclined. Komesu concerns himself to some extent with Yeats's interest and misunderstanding of things Eastern. On the whole, his discourse is in the American fashion of outsideness. Would it have been different if he had first studied Yeats in Ireland instead of with myself in America.[10l Or does his own critical tradition lend itself to a certain distance?

Surely something may be learned from both insider and outsider, and indeed both may be necessary or ought to be regarded as necessary to each other; but I suggest that, if one could, it would be better to endeavor to establish a third position neither inside nor outside (an impossibility, of course), suspicious of local political reductions, but also not content with an aestheticism that relaxes into a pure formalism. Such a position would be built out of opposition to both but also probably unthinkable without both, dependent on their languages if only to qualify them or say no to them, but with a positive force. This would have to be done without claiming an "objectivity" that the two opponents lack. In this way, it would speak from a sort of margin, but not for or necessarily toward the "impoverished, the illiterate, and the dislocated," the colonized, the colonizing, or the other marginalized groups mentioned in the daily press. It would have to be its own margin of self-liberating thought, always in the process of search (May we be speaking of Leopold Bloom here after all?), not to negate or oppress the interrelated opposites it opposes but to bring life into a stalled situation. 
It seems to me that humanistic discourse should always be at this task. Where East and West are concerned it must constantly seek a position at none of the compass points. Of course most of it will remain inside or outside, but that's all right. It is needed so that a few more venturesome souls can seek the margin. Not very economical, I'm afraid.

\section{Hazard Adams \\ University of Washington and \\ University of California, Irvine \\ Surface Page d'Acceuil/Home Page}

[1]Observer, 19, Education section (December 1993): 29.

[2]Irish Literary Supplement (Fall 1993): 21.

[3]Irish Literary Supplement (Fall 1993): 20.

[4]"An American View," Irish Times 22 (March 1952): 8.

[5]"Yeats and Antithetical Nationalism," Literature and Nationalism, eds. Vincent Newey and Ann Thompson (Liverpool: Liverpool University Press, 1991): 163-181.

[6]Celtic Revivals (London: Faber and Faber, 1985): 28, 33.

[7]Irish Literary Supplement (Spring 1989): 5.

[8]Modern Irish Poetry: Tradition and Continuity from Yeats to Heaney (Berkeley: University of California Press, 1986): 41.

[9]Preoccupations: Selected Prose, 1968-1978 (London and Boston: Faber and Faber, 1984): 101. I have had occasion to quote this passage previously in a forthcoming essay "Critic as Heaney," to be published in Critical Essays on Seamus Heaney, ed. Robert F. Garratt, G. K., Hall publisher. 
heavily in the debt of European critical theory. Cf. Karatani Kojin, Origins of Modern Japanese Literature, tr. Brett De Bary (Durham and London: Duke University Press, 1993), carries on a constant dialogue with it. Should we call this a colonialism? I hope not. 